\title{
The Meaning of Symbolic Interaction in the Towing Process
}

\author{
Vania Utamie Subiakto \\ School of Communication Science, Mercu Buana University \\ Jakarta, Indonesia \\ Email: vania.utamie [AT] mercubuana.ac.id
}

\begin{abstract}
The current study discusses the Meaning of Symbolic Interaction in the Towing Process among the Towing Officers from the Office of Transportation for Dealing with the Illegal Parking-Committing Four-Wheeled Vehicle Driver Communities. The objective of the study is to uncover, describe, and explain the meaning of symbolic interaction in the towing process by the Towing Officers from the Office of Transportation West Jakarta when they deal with the illegal parking committing four-wheeled vehicle driver communities on 2020. At the same time, the objective of the study is also to uncover the obstacles that the Towing Officers from the Office of Transportation West Jakarta should deal with when they have to ticket the illegal parking committing four-wheeled vehicle driver communities in 2020. Theoretically, symbolic interaction refers to the social life which basically deals with the interaction between the human beings and the use of the symbols. Therefore, symbols are not formed by mental force but, instead, symbols appeardue to the manings that the human beings have assigned. Thus, the specific focus of the study is to uncover how the Office of Transportation West Jakarta has made use of the symbols that represent the information within the towing process.

In conducting the study, the theory of Symbolic Interaction developed by Herbert Blummer was adopted in order to analyse the meaning of symbolic interaction in the towing process among the Towing Officers from the Office of Transportation West Jakarta in dealing with the Illegal Parking Committing Four-Wheeled Vehicle Driver Communities. In relation to the statement, the method that had been adopted was the case study. The datafor the study were gathered by means of three techniques namely: (1) observation; (2) in-depth interview; and (3) documentation. For guaranteeing the data validity, the source triangulation was adopted. Then, the results of the study show that the towing process by the Office of Transportation West Jakarta contains the symbols that have been represented to the communities. However, there are still arguments between the communities and the Towing Officers when the symbols are displayed during the transfer of the vehicles.
\end{abstract}

Keywords ----Symbolic Interaction, Illegal Parking, Towing, Office of Trans portation West Jakarta

\section{INTRODUCTION}

Several cases that have recently been found show that illegal parking committing has still taken place in many countries and this includes Indonesia as well. Most cases of the illegal parking committing have been found in the Jakarta Special Capitol which population migration figure has been the highest of all. As having been quoted fromthe data of the Central Bureau of Statistics Indonesia in 2018, the number of Jakarta population is 10.4 million people and this figure ranges from 0 to $65+$ years old. The data can be found in Table 1, which elaborates the Matrix of Jakarta Special Capitol Population.

Referring to the figure of Jakarta population, most of the population is found in the productive age namely $30-34$ years old (1,03 million people), followed by 35 - 39 years old ( 971,280 people), and 25 - 29 years old (965,850 people) (Badan Pusat Statis tik, 2018). Due to this phenomenon, and not to mention the fact that the number of Jakarta population has been increasing in each year, the rate of both motorcycle and automobile vehicle will steadily increase in each year. With reference to the statement, the Indonesian Joint Vehicle Industry (Gabungan Industri Bermotor Indonesia or Gaikindo) states that from January to June 2019 the figure of automobile wholesale in Indonesia has significantly decreased, namely $13 \%$, in comparis on to the same period within the last year (481,577 units from553,651 units). On the other hand, the Indonesian Association of Motorcycle Industry (Asosiasi Industri Sepeda Motor Indonesia) states that from January until June 2019 there have been 3,226,219 units of new motorcycle units sent to the dealers while in 2018 there have only been 3,002,753 units (Ruly Kurniawan, Perbandingan Jumlah Penjualan Mobil dan Motor Baru di Semester 1 2019, acces sed from https://otomotif.kompas.com/read/2019/08/02/143053915/perbandingan-jumlah-penjualan-mobildan-motor-baru-di-semester-i-2019 on December 15 ${ }^{\text {th }}, 2019$ 02:07 Western Indonesian Time). 
Table 1: Matrix of JakartaSpecial Capitol Population

\begin{tabular}{|r|r|r|r|}
\hline \multirow{2}{*}{$\begin{array}{l}\text { Kelompok } \\
\text { Umur }\end{array}$} & \multicolumn{3}{|c|}{ 2018 } \\
\cline { 2 - 4 } & \multicolumn{3}{|c|}{ Jumlah Penduduk Provinsi DKI Jakarta Menurut Kelompok } \\
\cline { 2 - 4 } & Laki-laki & Perempuan & Jumlah \\
\hline $0-4$ & 461794 & 444147 & 905941 \\
\hline $5-9$ & 472159 & 455206 & 927365 \\
\hline $10-14$ & 394643 & 370999 & 765642 \\
\hline $15-19$ & 355617 & 354567 & 710184 \\
\hline $20-24$ & 372793 & 411459 & 784252 \\
\hline $25-29$ & 468262 & 497588 & 965850 \\
\hline $30-34$ & 523215 & 508986 & 1032201 \\
\hline $35-39$ & 495643 & 475638 & 971281 \\
\hline $40-44$ & 429869 & 412091 & 841960 \\
\hline $45-49$ & 362091 & 349920 & 712011 \\
\hline $50-54$ & 296955 & 293992 & 590947 \\
\hline $55-59$ & 230049 & 236745 & 466794 \\
\hline $60-64$ & 167221 & 173024 & 340245 \\
\hline $65+$ & 214379 & 238577 & 452956 \\
\hline Jumlah & 5244690 & 5222939 & 10467629 \\
\hline
\end{tabular}

Sumber : Badan Pusat Statistik

Departing from the above data, the increasing figure of vehicle manufactured and distributed to the dealers and also purchased by the customers has resulted into new problems namely traffic jam and illegal parking activities among the two-wheeled vehicles and even the four-wheeled vehicles. The presence of the illeg al parking activities alone has resulted in the traffic jam as well. Such reality has been mostly found and has also been impossible to vanish from the daily scenery of the Jakarta Special Capitol. Although the officers from the Office of Transportation have performed the vehicle inquiry every single day, it seems that the rate of illegal parking activities among the four-wheeled vehicle driver communities has not even been diminishing.

Although the towing officers have been assigned everyday to monitor, to ticket, and to transfer any vehicle that commit illegal parking activities on the roadside, the number of violators is still high. According to Wildan (Kepala Seksi Pengendalian dan Operasional, 2019), the Office of Trans portation West Jakarta in coordination with the Dis trict-Level Task Force Office of Transportation in each area of West Jakarta has ticketed 4,408 four-wheeled vehicles in 2017, 393 four-wheeled vehicles in 2018, and 169 four-wheeled vehicles in 2019. Allof these four-wheeled vehicles were transfemed to the garage of the Office of Trans portation West Jakarta.

As having been previously explained, the penalty for the four-wheeled vehicle drivers who commit illegal parking activities on the roadside is that their vehicle shall be transferred to the garage that the Office of Trans portation West Jakarta has assigned. With reference to the penalty, August Fabian states that the law enforcement that refers to the Article 140 of the Regional Government Regulation Number 5 of 2014 on the Traffic Arrangement in the Capitol has been unable to eradicate the illegal parking activities (an interview with August Fabian, the Head of Law Enforcement Section, the Domain of Operational Control the Office of Transportation the Jakarta Special Capitol, on February $9^{\text {th }}, 2019$ ).

The illeg al parking activities have taken place within the community due to the lack of the available parking areas. At the same time, the expensive rate of parking area in the Jakarta Special Capitol has urged the four-wheeled vehicle owners to park their vehicles over the roadside. This situation asserts why the as pect community education is important to implement by the officials from the Office of Transportation. In other words, the officials from the Office of Tran sportation should provide socialization and information to the community with regards to the illeg al parking activities. With reference to the statement, the towing process by the Office of Transportation dis plays a symbolic interaction among the Towing Officers, the four-wheeled vehicle drivers, and the surrounding community. In this regard, the symbolic interaction is the process of message communication through certain symbols among them. 
The theory of symbolic interaction posits that meaning appears to the surface as the results of an interaction among human beings both verbally and non-verbally. Through the action and the response that have taken place, human beings as sign meaning to their word s or actions and thereby human beings are able to understand an event through certain manners (Moris san, 2013: 110). According to Soekanto (1982: 8), the theory of symbolic interaction as sumes that the basis of a communal life among human beings is communication and, in this regard, symbols become the ey to understand the social life of human beings. A symbol itself can refer to a mark, an object, or a movement that has socially been considered as possessing certain meanings. Returning to the case of the towing process, the communication pattern that has been established by the officers from the Office of Transportation West Jakarta with the four-wheeled vehicle drivers and the surrounding community provides different results. These differences are caused by the different frame of references and the different field of experiences that an individual has. The different frame of references and field of experiences are resulted from the different cultures that different people have. In this context, culture can be defined as a concept that triggers an interest. In a formal manner, culture can also be defined as an overall pattern (Mulyana, 2002: 26).

What people observe, what people dis cuss, how people discuss, what people pay attention to, what people abandon, what people think, and how people think are influenced by culture. Thus, in turn what people talk, how people talk, and what people see will shape, define, and animate the culture. Similar principle also applies to the four-wheeled vehicle drivers who commit illegal parking activities by parking their vehicles on the roadside. These vehicle drivers also come from different cultures and, unfortunately, most of the violators are fromoutside Jakarta Special Capitol.

In order to conduct the study on the meaning of the symbolic interaction among the Towing Officers, the fourwheeled vehicle drivers who have been ticketed, and the surrounding community, the scope of the study should be limited in order to facilitate the easy data management. Thus, the focus of the present study is on the function of the interaction symbolic among the Towing Officers, the four-wheeled vehicle drivers who have been ticketed, and the surrounding community. With regards to the focus of the study, the problems in the study are formulated as follows: (1) What is the meaning of the symbolic interaction in the towing process b y the Towing Officers from the Office of Trans portation West Jakarta for dealing with the four-wheeled vehicle drivers who commit illegal parking activities in 2020?; and (2) What are the obstacles that the Towing Officers from the Officer of Transportation West Jakarta have in dealing with the fourwheeled vehicle drivers who commit illegal parking activities in 2020 ?

\section{Theory of Sym bolic Interaction}

\section{LITERATURE REVIEWS}

The theory of symbolic interaction puts emphasis on the relationship between symbols and interactions and the core of this approach lies in individuals (Soeprapto, 2007). In this domain, there are many experts who state that individuals are the most important aspect in the concept of s ociology. Theory of symbolic interaction posits that meaning appears as the result of interaction among human beings both in verbal and non-verbal manner. Through the actions and the responses that have taken place, human beings as sign meaning into the words and the actions and therefore human beings are able to understand certain events through certain manners (Moris san, 2013: 110). According to Soekanto, (1982: 8), theory of symbolic interaction assumes that the basis of communal life among human beings is communication, es pecially the communication of symbols, which has been the key to understand the social life of human beings. In this context, a symbol refers to the social mark, object, or movement.

The principle of symbolic interaction methodology is that the symbol and the interaction are united and therefore recording facts will be sufficient; in other words, context should be furtheridentified in order that the actual symbol and meaning can be comprehended. Then, the understanding toward the principles of symbolic interactionism has interest on (1) the way in which human beings use symbols to reveal what they mean and to communicate fromone to another, and (2) the impact of the symbolinterpretation toward the actions of the involved parties during the social interaction (Jones, 1979). The results of several previous studies show that the same contemplation on meaning in symbolic interaction is highly necessary in manifesting common understanding and harmonization. For example, these studies view: (1) the process of symbolic interaction occurrence between the players and the spectators, the existing symbols, and the symbols that have been used in es tablishing the symbolic interaction between the players and the spectators (Kus umastuti, 2006); and (2) the meaning contemplation in actualizing the values of the ancestors within the Chinese neighbourhood on the trading communication network (Anugrahani, 2014). The peculiar characteristics of symbolic interaction that lies in the emphasis on human beings during the process of mutual interpretation and mutual action definition are not directly established between stimulus and response but, instead, are based on the contemplation on the meaning that has been as signed in to the actions of other people through the use of symbols and interpretations and eventually each individual will strive to understand the intention and the action fromone another in order to achieve common agreement (Siregar, 2011).

\section{Theory of Symbolic Interaction from the School of Herbert Blumer}

Herbert Blumer, a Profess or from the University of California in Berkeley, have striven to integrate the concepts of Mead into a theory of Sociology known as the Theory of Symbolic Interaction. In his article entitled Sociological Implications of the Thought ofGeorge Herbert Mead (American Journal of Sociology, 71, 1966: 535-544), and then in his bookentitled Symbolic Interactionism: Perspective andMethod (1969), he refers to the five concepts of Mead namely:(1) Self; (2) Action; (3) Object; (4) Social Interaction; and (5) Joint Action. In addition, Blu mmer states that symbolic 
interaction refers to the joint actions that have the capability to establish a structure or an institution due to the symbolic interaction in delivering themeaning through the use of cues and languages. Through the meaning-contained symbols, the objects that have been limited and interpreted through the process of meaning interaction are delivered to another party.

\section{Symbol and Meaning}

Symbolrefers to the social object within an interaction that has been used as a representation and a communication defined by the people using it and, therefore, symbol as signs meaning in to the object and alsocreates and alters the object within an interaction. Symbol can be considered as a shape that marks an entity outside the manifestation of the symbolic form itself. In the concept of Pierce, symbol is defined as the mark that refers tocertain objects outside the mark itself. The relationship between symbol as the marker and the object as the marked is conventional. Based on such convention, the user community of the symbol interprets the characteristics on the relationship between the symbol and its referred object and the meaning of the symbol.

\section{METHOD}

The study adopted the constructivist paradigm and the object of the study was the Symbolic Interaction on the meaning of towing process performed by the Towing Officers from the Office of Transportation West Jakarta in dealing with the four-wheeled vehicle driver community that committed the illegal parking activities in 2020 . The symbolic interaction in the study referred to all aspects that had been mutually related to one another as the establishment of the meaning from an object or a symbol, both in the form of inanimate things and in the form of animate things, through the process of verbal and non-verbal communication. In conducting the study, the final object that had been defined was to interpret the symbol or the object based on the governing common agreement in certain area or community group.

Then, the method that had been adopted in conducting the study was the case study. In the case study, the researcher involved theinformants from the Office of Transportation West Jakarta. these informants were:

a. The Head of the Office of Trans portation West Jakarta

b. The Field Coordinator of the Office of Trans portation West Jakarta

c. The Towing Officers of the Office of Transportation West Jakarta

Futhermore, the nature of the study was a qualitative researcher. In gathering the relevant data, the data were collected from the direct observation in the Office of Transportation West Jakarta, the interview with the Person in Charge and the Towing Officers from the Office of Transportation West Jakarta, and the documentation study. After the relevant data had been completely gathered, the data were analysed by using the qualitative approach through the case study method. Within the analysis, the focus was on how the symbolic interaction between the Towing Officers from the Office of Trans portation West Jakarta and the illeg al parking-committing four-wheeled vehicle driver community in 2020. All of the data in the analys is were triangulated in order to pres erve the data validity. As a procedure for ens uring the data validity, the triangulation was performed by benefitting something outside the data in order to check or to compare the data.

\section{RESULTS AND DISCUSSIONS \\ The Occurence of Symbolic Interaction within the Towing Process by the Office of Transportation West Jakarta in Dealing withe Illegal Parking-Committing Community}

The towing action by the Towing Officers fromthe Office of Trans portation West Jakarta is not a taboo anymore. Every single day the towing officers always ticket the people who do not park their vehicles on the available space. The towing itself can also be based on the complaint from the community whose roadside has been used for the illegal parking activities. For example, in Kaliangke Village, West Jakarta, the Towing Officers ticket the four-wheeled vehicle drivers who committed the illegal parking activities on Pesing Polgar Street. The Platoon Commander from the Third Sector of the Office of Trans portation West Jakarta states that the result of the towing action on that day are four personal fourwheeled vehicles and 1 truck have been transported to the Office of Trans portation West Jakarta Garage.

The towing process is not apart from the social situations among the community residents whoconsider that every single piece of a street can be used for parking activities. For example, the community residents in West Jakarta rarely have a garage for parking their four-wheeled vehicle and, consequently, these vehicles will be parked on the roadside. In the long term, this situation becomes very concerning especially when these vehicles have caused traffic ja m. Due to the such problem, the Provincial Government of Jakarta Special Capitol has issued a regional regulation that defines the trans portation arrangement of the Indonesian citizens who live in West Jakarta namely the Regional Regulation of Jakarta Special Capitol Number 5 of 2004. In the Regulation, a transportation system is discussed and and considered for implementation in order to manifest a reliable transportation in accordance with the position and the authority of the Province of Jakarta Special Capitol. The system, named Trans portation Regulation System, has been published in the Website of the Office of Transportation Jakarta Special Capitol and the context of the trans portation regulation becomes the res ponsibility of the Office of Transportation in each province throughout the Republic of Indonesia, including Jakarta Special Capitol.

The appearance of the towing problems has been a peculiar polemic in Indonesia. Specific to the case of Jakarta Special Capitol, the towing policy that has been implemented is already a peculiar problem whereas asserting the importance of maintaining convenience and fluency during the drive should actually be a new kind of awareness among 
individuals who live in West Jakarta. This problem thus become more complicated since the towing policy has been implemented by the Office of Transportation throughout the five admins itrative cities of Jakarta Special Capitol namely: (1) the Office of Trans portation W est Jakarta; (2) Office of Trans portation North Jakarta; (3) Office of Trans portation East Jakarta; (4) Office of Trans portation Central Jakarta; and (5) Office of Trans portation South Jakarta.

The is suance of the to wing policy in the Regional Regulation has been due to the fact that the number of the drivers in Jakarta is linear with the increasing needs of parking areas. Nowadays, Jakarta has been suffering from the minimum number of free-charge parking areas made available by the local government. The high number of shopping buildings and skyscrappers has resulted in the minimum parking areas whereas the needs to ward the parking area availability has been increasing. The situation becomes more complexsince the prohibition of illegal parking activities on the roadside has been stated in Law Number 22 of ... . The consequence of the violation toward the Law is that the vehicles will be transferred to the nearby garage of the Office of Trans portation.

The towing process in West Jakarta takes place when the Towing Officers from the Office of Transportation West Jakarta monitor the vulnerable points of illegal parking activities on the roadside. Usually, the Towing Officers monitor certain points such as Puri Indah, South Meruya, Kembangan, Cengkareng, Central Jakarta, Taman Sari, and alike by driving the Towing vehicles. The aim of the monitoring is to clear the roadside from the illegal parking activities, which are usually committed by the surrounding community residents or the visiting community residents namely: (1) online trans portation drivers; (2) expedition drivers; and (3) good and service tran sportatin drivers.

The Towing Officer usually monitor the vulnerable points around 07:00 Western Indonesian Time after the moming debrief in the Office of Transportation West Jakarta (an interview with Lamudin, the Supervis or of the Office of Trans portation West Jakarta, on February $18^{\text {th }}, 2020$ ). In monitoring the vulnerable points, the Towing Officers are divided into several groups and each group consists of three Towing Officers. The monitoring process has been daily performed and the data that have been compiled in 2018 show that 4,155 four-wheeled vehicles have been transferred to the garage of the Office of Transportation West Jakarta.

Due to the Regional Regulations that have been is sued, not all locations in the Province of Jakarta Special Capitol can be turned into parking areas. Although there is not any sign of parking prohibition, the four-wheeled vehicles that have been found parking on the roadside will be transferred to the garage of the Office of Transportation West Jakarta (an interview with Lamudin, the Supervis or of the Office of Transportation West Jakarta, on February $18^{\text {th }}, 2020$ ). In towing the the four-wheeled vehicles that have been involved in the illegal parking-activities, the Towing Officers refer to the Regional Regulation of the Jakarta Special Capitol Number 5 of 2014 on Transportation and other regulations on the parking activities. According to the Regional Regulation, the criteria for the legal road parking activities are as follows:

\section{pasal36}

(1) The opening of the parking areas on the side of the road as having been intended in Article 35 Verse 1 should pay attention to:

a. The width of the street;

b. The volume of the traffice

c. The characteris tics of the speed;

d. The dimension of the vehicles; and

e. The role of the pertinent road

Then, the regulations on the road sign have been strictly defined in Article 38, which states that:

\section{pasal38}

(1) The sides of the road that have been opened for parking areas should be equipped with the Parking Sign.

(2) Every owner and / or driver is not allowed to park their vehicles over the sidents of the road that have not been equipped with the Parking Sign.

Therefore, with reference to the Regional Regulatuin of Jakarta Special Capitol Number 5 of 2014 on Trans portation, there are three types of actions that will be made toward the violators of the parking rgulations namely: (1) locking the tyres of the vehicles; (2) towing the vehicles; and (3) removing the tire valve. These actions are applied to all kinds of motor-engined vehicles. Specific to the towing process, the regulations on towing either then four-wheeled vehicles or the two-wheeled vehicles have been defined in the Gubernatorial Regulation of Jakarta Special Capitol. The latest regulation that holds the arrangement on the towing process in the Gubernatorial Regulation Number 31 of 2017, which was approved by Sumars ono as the Acting Governor of Jakarta Special Capitol at that time. In this regulation, it is as serted that the gvehicles of drivers who violate the parking regulation will be towed and transferred to the nearby garage of the Office of Transportation. After the vehicles have been towed and transferred, the drivers should pay for the ticket and later the vehicles will be returned to the drivers. In the case of vehicle pickup, the drivers may send a representative who has been provided with the valid vehicle regis tration certificate of the int ended vehicles (an interview with Lamudin, the Supervisor of the Office of Trans portation West Jakarta, on February $18^{\text {th }}, 2020$ ). 
For picking up the four-wheeled vehicles that have been towed, the retribution that should be donated refers to the Article 29 of the Gubernatorial Regulation of Jakarta Special Capitol Number 31 of 2017 namely IDR 500,000.00 (five hundred thousand rupiahs) per day with the maximum rate IDR 3,000,000.00 (three million rupiahs). The rate of retribution is adjusted to the 6-day tariff fromthe towing process. If the four-wheeled vehicles that havebeen towed are not picked up for more than 6 six days, the Towing Officers from the Office of Trans portation West Jakarta shall not be held res ponsible for the los s and the damage of the vehicles. The procedures for picking up the four-wheeled vehicles that have been towed by the Towing Officers of the Office of Transportation West Jakarta are as follows (an interview with Lamudin, the Supervis or of the Office of Trans portation West Jakarta, on February $18^{\text {th }}, 2020$ )

1. Send a short mes sage service (SMS) to 0857-9920-0900 in order to attain the Virtual Account for the payment of the fine with the following form: PARKING (space) Vehicle Reg is tration Certificate

2. Pay the amount of the fine to the Shared ATM or the Teller of Bank DKI

3. Show the payment receipt to the Officer in the Office of Transportation where the four-wheeled vehicles have been towed to

4. Wait for the verification and the is suance of Vehicle Is s uance Certificate after the payment receipt has been s hown

5. Show the Vehicle Is suance Certificate to the Officer in Charge and pickup the four-wheeled vehicle

\section{The Process of Sym bolic Interaction within the Towing Officers of the Office of Transportation West Jakarta for Dealing with the Illegal Parking-Com mitting Community}

Towing is one of the actions that the Office of Transportation West Jakartahas taken in the efforts of enforcing the traffic order and warning the vehicle drivers to adhere to the governing parking regulations in the Province of Jakarta Special Capitol, es pecially in the area of West Jakarta. In towing the four-wheeled vehicles under the case of illegal parking activities, the Office of Transportation West Jakarta relies on the use of the Qlue Report. The Head of the Office of Trans portation West Jakarta, Erwan syah, has instructed the members of the Office of Transportation West Jakarta to follow up the Qlue Report with regards to the illegal parking activities on the road side and on the public facility (an interview with Erwansyah, the Head of the Office of Transportation West Jakarta, on June $30^{\text {th }}, 2020$ ). In addition, the Office of Trans portation West Jakarta als o performs joint actions that involve the members of the Office of Transportation West Jakarta, the members of the Indonesian National Army, the members of the Indonesian Police Department, and the state apparatus from the nearby Dis trict in taking steps toward the illegal parking activities based on the public report fromthe Qlue Application. For example, the Officers from the Office of Trans portation West Jakarta have towed the four-wheeled vehicles fromNorth Kembangan Street, Main Kembang an Asri Street, PuriIndah Street, TamboraStreet, and alike due to the illegal parking activities. In addition to following up the public report, Erwan s yah has instructed the Towing Officers in the Office of Trans portation West Jakartato monitor and put in order all vehicles in the vicinity of W est Jakarta and the four-wheeled vehicles that have not been parked on the appropriate shall be towed to the a vailable space or to the garage of the Office of Trans portation West Jakarta. After the suspected four-wheeled vehicles havebeen towed to the garage, the violators should pay retribution rate approximately IDR 500,000.00 / day in order to pick up the vehicles. The towing process that the Towing Officers from the Office of Trans portation West Jakartais presented in Figure 1 below.

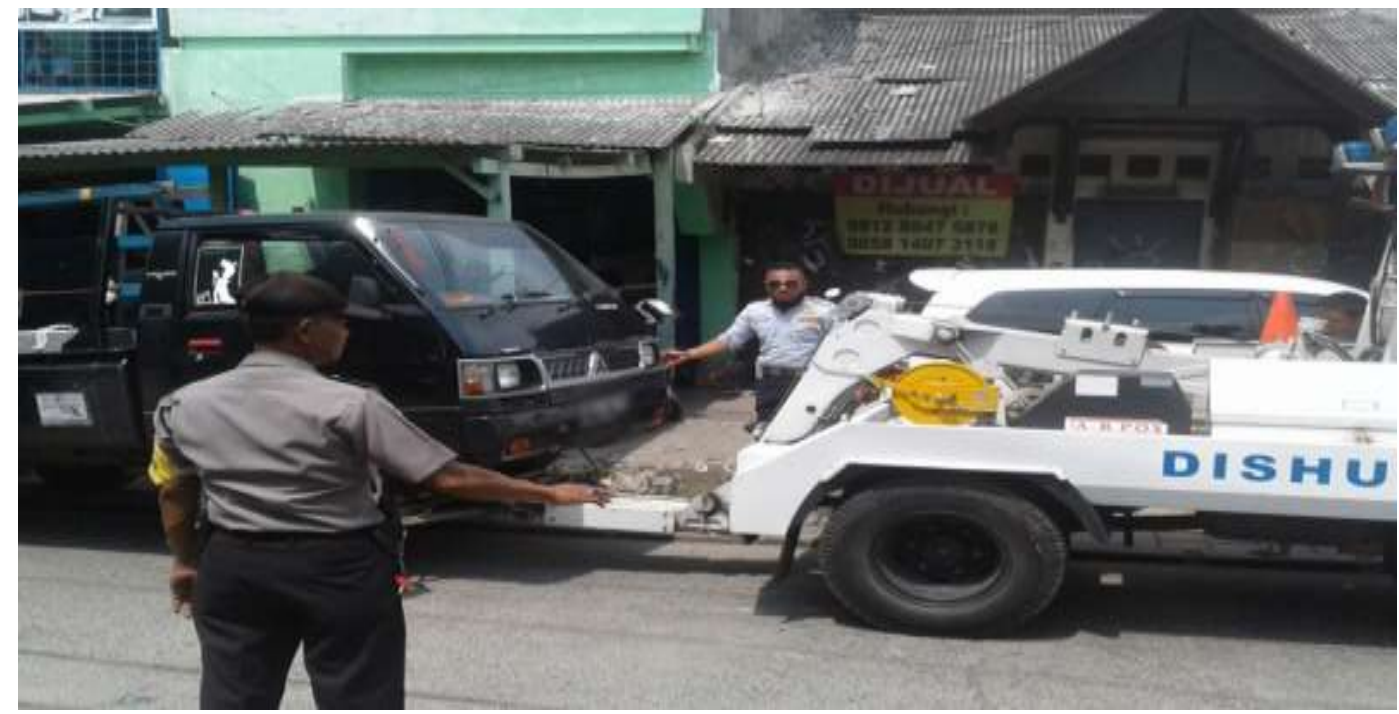

Figure 1: Process that the Towing Officers from the Office of Transportation West Jakarta Source : The Office of Trans portation Jakarta 
The Office of Transportation West Jakarta has 10 teams of Towing Officers and each team consists of 3 Towing Officers whose age is between 24 years old and 45 years old. Each team will establish coordination with the Operation Control, which is responsible for the towing decision by the Officers every day. Then, the background of the Towing Officers is various, ranging from Senior High School or Vocational High School Graduates until Strata-1 Graduates. The Towing Officers always put on the official uniform in every towing process on the road. In conducting their duty, each team of Towing Officer is equipped with one Towing vehicle operated by 3 Towing Officers.

The Head of the Office of Transportation West Jakarta always debrief the Towing Officers every morning before the officers performtheir duty in both the Office of Trans portation W est Jakarta and the Region of West Jakarta. Within the debrief, Erwansyah states that each member should put forward their ethics in perfoming the towing process. If the four-wheeled vehicle is empty, the Towing Officers are obliged to transfer the vehicle to the available space. All of these procedures are based on the Regional Regulation of Jakarta Special Capitol Number 5 of 2-14 on Transportation and the Gubernatorial Regulation of Jakarta Special Capitol Number 31 of 2017.

In the practice, the towing problem that has been generally perceived by the home residents or the visiting residents in the Administrative City of West Jakarta is the anger when their four-wheeled vehicles have been towed (an interview with Afandi, the Acting Head of Operation Control the Office of Transportation West Jakarta). However, the towing process has been in accordance with the Standard Operating Procedures of the Office of Transportation and indeed in most cases it is found that the vehicles have been parked over the roadside despite the parking prohibition sign and the excuse is always "making a pit stop due to an urgent matter." This situation has always been explained by Afandi in every morning debrief prior to the conduct of the duty by the Towing Officers.

The actions that the Towing Officers have performed are in accordance with the in struction of the Pers on in Charge namely not to use coercion or even violence. If the violators are asleep in the four-wheeled vehicles, then the Towing Officers should strive to wake up the violators for several times. When there is not any response from the violators, the officers are allowed to immediately tow the four-wheeled vehicles. In another occasion, every time the violators are not available in the four-wheeled vehicles then the officers will put on a sticker over the vehicle to inform the violators that their four-wheeled vehicles have been towed and transferred to the Office of Tran sportation West Jakarta Garage.

The concept of the Office of Trans portation in enforcing the traffic regulation pursues more of humanis tic approach between the Towing Officers and the violators by not using any coercion and even violence in towing the illegally parked four-wheeled vehicles. In addition, the Towing Officers always verify the complaint reports that they have daily retrieved from the public through the CRM application before following up the complaint reports. Prior to executing their duty, the Towing Officers visit and observe scene and also investig ate whether the complaint reports have been valid or not. The interaction between the humanistic Towing Officers from the Office of Transportation and the surrounding community residents is manifes ted by the discussion and dialogue patterns between them.

The public complaints about their concerns toward the illegal parking on the roadside have been related to the absence of the garage in the settlement of the four-wheeled vehicles" owners. Indeed, the community residents who have parked their four-wheeled vehicles over the roadside has been concerning for the surrounding neighbourhood since the presence of the four-wheeled vehicles invites traffic jam and noise due to the honks. In this regard, theinteraction between the Towing Officers and the concerned community residents relies on the implementation of CRM s ys tem. In this system, the complaint reports that have been filed will be marked with Red Code and when the complaints have been settled by the Towing Officers the Red Code will turn into the Yellow Code.

The CRM application is not only u sed for filing the roadside parking complaints but also complaints fromall as pects in the settlement life such as waste management, flood, and alike. These complaints are usually followed up by the relevant Office in the Adminis trative City of W est Jakarta (an interview with Affandi, the Acting Head of Operation Control the Office of West Jakarta). The communication pattern that has been frequently established between the community residents and the Towing Officers is both the symbolic interaction and the meaning interaction by simulating or socializing the illegal parking prohibition despite the absence of the parking prohibition sign.

The typical reason that the violators have always stated is related to the absence of parking prohibition sign whereas actually the prohibition sign should not be placed at all points. The reason is that placing the parking prohibition sign at all points will be ineffective and instead will case inconvenience for the four-wheeled vehicle drivers. Because of such typical reason, most of the time the Towing Officers and the violators are involved in an argument and due to the argument the Towing Officers should take preventive measures by towing the illegally parked four-wheeled vehicles, resulting in the resis tance by both the violators and the surrounding community residents. In order to avoid the argument, the Person in Charge from the Office of Trans portation West Jakarta has ins tructed the Towing Officers to provide thorough and detailed explanation on the towing regulations that have been stated in the Gubernatorial Regulation of Jakarta Special Capitol.

\section{The Symbols in the Towing Process by the Office of Transportation West Jakarta}

The towing process is performed by 10 teams of Towing Officers with each teamconsisting of 3 Towing Officers. Every day these teams monitor the traffic in numerous vulnerable points throughout the Administrative City of West Jakarta. In this regard, the towing process can be contemplated as a process of law enforcement on the violators whohave illegally parked their four-wheeled vehicles over the roadside and the towing process itself has been regulated by the Regional Regulation of Jakarta Special Capitol Number 5 of 2014 on Transportation and the Gubernatorial Regulation of 
Jakarta Special Capitol Number 31 of 2017. In the law-enforcing action, the towing process by the Office of Transportation West Jakarta is always performed by the Towing Officers with complete uniform and attribute. These officers have been as signed to arrange the traffic and provides convenience by cleaning the roadsides from the illegally parked four-wheeled vehicles. The uniform that the towing officers always put on in carrying out the towing process is presented in Figure 2 below.

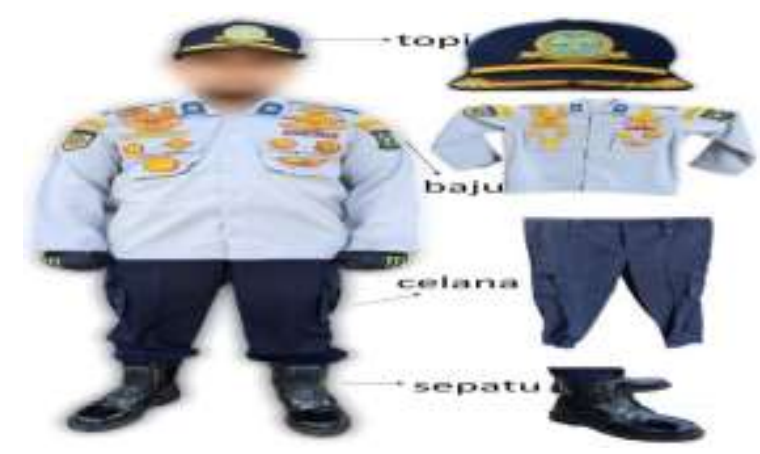

Figure 2: The Uniform That The Towing Officers Sumber Source : The Office of Transportation Jakarta

West Jakarta Administration City Transportation Sub-department crane officers in monitoring traffic and taking action against illegal parking offenders are carried out every morning at 7clock. Every teamconsists of 3 Towing Officers and in monitoring the traffic this team is as signed with a towing vehicle. The towing vehicle that has been assigned by the Office of Trans portation West Jakarta is presented in Figure 3 below.

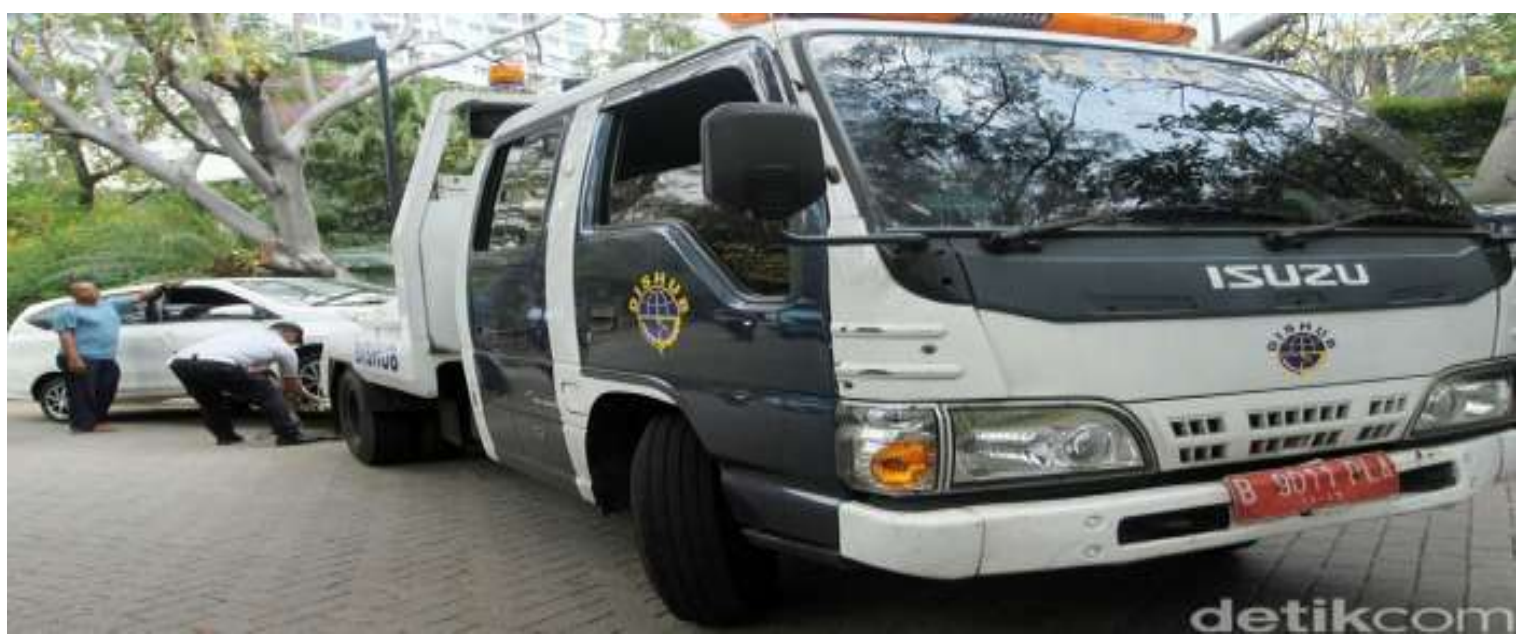

Figure 3: The towing vehicle that has been assigned by the Office of Transportation West Jakarta Source : detik.com

The towing vehicle that has been assigned facilitates the Towing Officer in transferring the illegally parked fourwheeled vehicles on the roadside or even the road marks. The siren from the towing vehicle or the warning from the Towing Officers becomes a symbol that the community residents should immediately move their four-wheeled vehicles or leave the illegal parking areas. If the four-wheeled vehicles that have been illegally parked are found without the owners or the drivers then these vehicles will be immediately towed and transferred to the Office of Transportation West Jakarta Garage. Prior to the towing and the transfer, the Towing Officers put on a sticker containing information that the four-wheeled vehicles with the pertinent Vehicle Registration Certificate has been transferred to the Office of Transportation West Jakarta Garage. The information about the towing process for the four-wheeled vehicles that have been illegally parked is presented in Figure 4 below. 


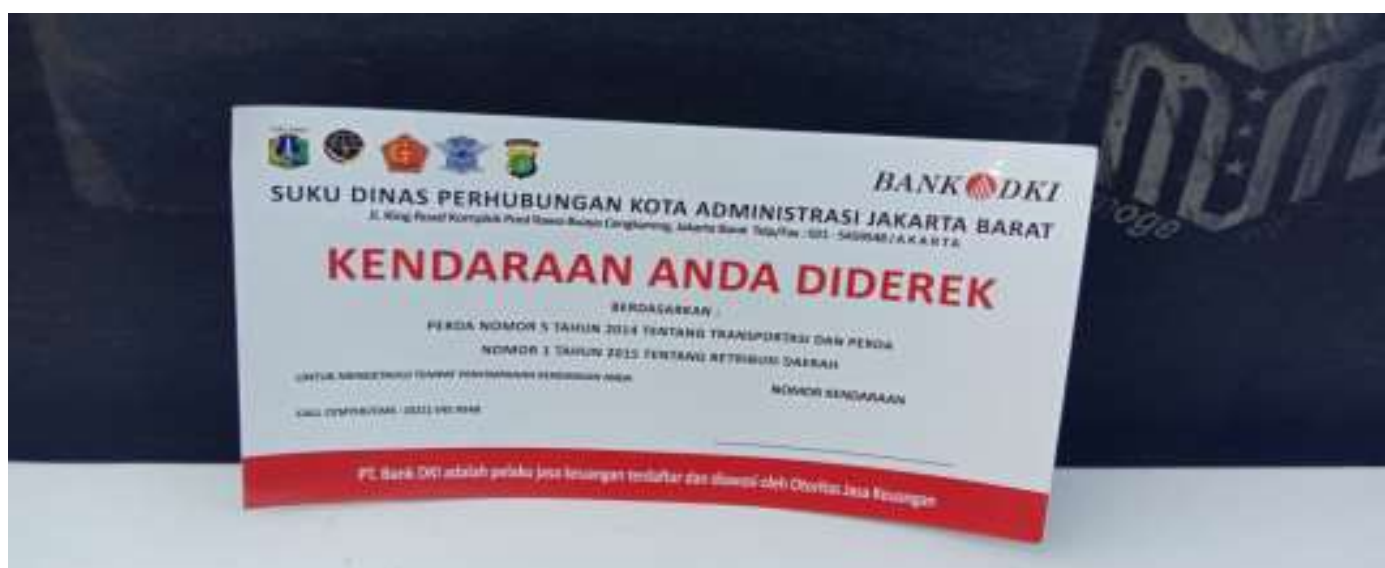

Figure 4: The Information about the Towing Process for the Four-Wheeled Vehicles That Have Been Illegally Parked

Source: Sumardin, the Office of Trans portation West Jakarta

The Towing Officers do not directly tow the illegally parked four-wheeled vehicles; ins tead, the Towing Officers es tablish a communication with the community residents by using the speakers from the towing vehicle so that the drivers or the owners of the four-wheeled vehicles with the pertinent Vehicle Regis tration Certificate move the vehicles. If the drivers or the owners of the illegally parked four-wheeled vehicles are not in the place, then the Towing Officers will immediately tow and transfer the pertinent four-wheeled vehicles. This explains why whenever there is a towing vehicle nearby the community residents already understand that there will be towing process for the four-wheeled vehicles that have been illegally parked over the road marks. Therefore, the driv ers or the owners of the pertinent four-wheeled vehicles will drive fast in order to avoid the towing process. The towing process itself is performed on the working days namely Monday to Friday. Des pite the massive efforts of law enforcement on the traffic order and in specting the illegally parked four-wheeled vehicles, not all roads can be monitored by the Towing Officers from the Office of Transportation West Jakarta especially in the case of settlement complex. The reason is that the Towing Officers are only able to reach the major arterial roads located in the Adminis trative City of West Jakarta.

\section{The Obstacles of the Towing Officers from the Office of Transportation West Jakarta in Dealing with the Illegal Parking-Committing Four-Wheeled Vehicle Driver Community in 2020}

In establis hing interaction with the community residents, especially the perpetrators of the illeg al parking activities, the Towing Officers should deal with the significant obstacle namely the absence of the parking prohibition sign. In addition, other obstacles that the Towing Officers have been frequently dealing with in establishing the interaction with the residents of the community in which the illegally parked four-wheeled vehicles should be towed and temporarily transferred to the Office of Transportation West Jakarta are as follows:

1. Most of the community residents, or the illegal-parking perpetrators, are not originally from the Province of Jakarta Special Capitol or even from the Administrative City of West Jakarta. These people are from outside the Province of Jakarta Special Capitol or the Administrative City of West Jakarta such as South Tangerang, Depok, Bekasi, Banten, Central Java and alike. They often admit that they do not know any information about the towing process and they always complaint that they have to pay IDR 500,000.00 as the retribution rate for their four-wheeled vehicles.

2. Most of the community residents do not accept the decision that their four-wheeled vehicles should be towed and temporarily transferred by the Officers.

3. The Towing Officers and the community residents always argue that there has not been any parking prohibition sign over the pertinent area.

4. The community residents rarely learn from their mis takes and yet they will stop when their four-wheeled vehicles have been towed and temporarily transferred for two or three times (an interview with Sumardin, the Team Commander of Towing Officers from the Office of Transportation West Jakarta).

\section{CONCLUSION}

Based on the results of the analysis and the discussion on the Meaning of Symbolic Interaction on the Towing Proces s among the Towing Officers from the Office of Transportation West Jakarta for dealing with the Illegal Parking Committing Four-Wheeled Vehicles DriverCommunity, there are several conclusions that can be drawn namely:

1. The execution of the towing process should be based on the Standard Operating Procedures that have been is sued by the Office of Trans portation Jakarta Special Capitol, which has been based on the Regional Government of Jakarta Special Capitol Number 5 of 2014 on Transportation and the Gubernatorial Regulation of Jakarta Special Capitol Number 31 of 2017. 
2. The towing process should be officially performed by the Towing Officers every day as part of the duty that has been as signed by the Office of Trans portation West Jakarta.

3. The execution of the towing process bears a symbol that can be interpreted as having peculiar meaning form the interaction between the Towing Officers and the community residents, es pecially the illegal-parking perpetrators.

4. In executing the towing process, many symbols have been assigned to the community residents such as: (a) the Towing Officers in theircomplete uniform; (b) the presence of the towing vehicle; (c) the warning and the suggestion about the prohibition to park the four-wheeled vehicles over the road marks to the community residents; and (c) the sticker containing information that the four-wheeled vehicles been illegally parked on the roadside or the road marks.

5. The towing process is performed by 10 teams of Towing Officers, each of which consisting of three Towing Officers.

\section{REFERENCES}

- Anugrahani. (2014). "Pemaknaan Etnis Tionghoa dalam Mengaktualisasikan Nilai Leluhur pada Bisnis Perdagangan (Studi Fenomenologi Jaringan Komunikasi Pedagang Tionghoa di Kabupaten Kediri)”. Jumal Penelitian Ilmu Komunikasi. 1 (1): 1-16.

- Afandi, Plt Dalops Suku Dinas Perhubungan Kota Administrasi Jakrata Barat padatanggal 20Februari 2020

- Badan Pusat Statistik, Profil Penduduk Indonesia Hasil Supas 2015, diakses di https://www.bps.go.id/publication/2016/11/30/63daa471092bb2cb7c1fada6/profil-penduduk-indonesia-hasilsupas-2015.html, pada tanggal 15 Desember 2019 puku101.49 Wib.

- Dwi Hadya Jayani, 2019, diakses di https://databoks.katadata.co.id/datapublish/2019/09/10/jumlah-penduduk-dkijakarta-2019-mencapai-105-juta-jiwa,

- Dinas Perhubungan DKI Jakarta, 2020, diakses di https://dishub.jakarta.go.id/ketentuan-parkir/

- Dinas Perhubungan DKI Jakarta, 2020, diakses https://dishub.jakarta.go.id/suku-dinas-perhubungan-jakarta-barat/

- Erwansyah, Kepala Suku Dinas Perhubung an Kota Administrasi Jakarta Barat pada tang gal 30 Juni 2020

- Fabian August , Kepala Seksi Penegakan Hukum(Gakum) Bidang Pengendalian Operasional (Dalops) Dis hub DKI Jakarta, pada tanggal 9 Februari 2019.

- Goldhaber, G.S. (1993). OrganizationalCommunication. New York: Mc Graw-Hill

- Haliemah Noor dan Rama Kertamukti, Program Studi Ilmu Komunikasi UIN Sunan Kalijaga Yogyakarta, Interaksi Simbolis Masyarakat Dalam Memaknai Kesenian Jathilan, Jurnal ASPIKOM, Volume 3 Nomor 3, Juli 2017, hlm 494-507

- Jones, P. (1979). Pengantar Teori-Teori Sosial. Jakarta: Raja Grafindo Persada.

- Kusumastuti, E. (2006). "Laesan sebuah Fenomena Kesenian Pesisir: Kajian Interaksi Simbolik antara Pemain dan Penonton". Harmonia Jurnal Pengetahuan Dan Pemikiran Seni.7 (3): 10-19.

- Liliweri, Alo. (2003). Makna Budaya Dalam Komunikasi Antar Budaya. Yogyakarta:LkiS

- Lamudin,Pengawas Suku Dinas Perhubungan Kota Adminis trasi Jakarta Barat padatanggal 18 Februari 2020

- Mulyana, Deddy. (2001). Ilmu Komunikasi Suatu Pengantar. Bandung: PT. Remaja Rosdakarya.

- Mulyana, Deddy; Rakhmat, Jalaluddin. (2002). Komunikasi Antarbudaya, Bandung: PT. Remaja Rosdakarya.

- Morris an. 2013 Teori Komunikasi, Penerbit Ghalia Indonesia, Bogor.

- Poloma, M. (2007). Sosiologi Kontemporer. Jakarta: Raja Grafindo Persada.

- Peraturan Daerah NOMOR 5TAHUN 2014 TENTANG TRANSPORTASI

- Peraturan Gubernur (Pergub) DKI Jakarta y aitu Pergub No 31 Tahun 2017.

- Ruly Kurniawan, Perbandingan Jumlah Penjualan Mobil dan Motor Baru di Semester 1 2019, diakses di https://otomotif.kompas.com/read/2019/08/02/143053915/perbandingan-jumlah-penjualan-mobil-dan-motorbaru-di-semester-i-2019,

- Ruslan, Rosady, S.H., M.M., Manajemen Public Relations dan Media Komunikasi; Konsep danaplikasi, (Jakarta; Raja Grafindo Persada, 2012)

- Ritzer G, Douglas JG. (2010). Teori SosiologiModern. Jakarta: Kencana.

- Siregar NSS. (2011). “Kajian Tentang Interaksionisme Simbolik”. Pers pektif Jurnal Isipol UMA. 4 (2): 100-110.

- Samovar,Larry; Porter, Richard. (2003). Intercultural Communication A Reader 10th Edition. Belmont, Ca:Wa ds woth Publishing Company.

- Subiakto Utamie Vania, Strategi Sosialisasi Kebijakan Penderekan Oleh Suku Dinas Perhubungan Jakarta Barat, CoverAge:Journal of Strategic CommunicationVol. 9, No. 2, Hal. 31 -42.Maret 2019.

- Sumardin, Danru Derek Suku Dinas Perhubungan Kota Adminis trasi Jakarta Barat

- Vardiansy ah Dani, Filsafat Ilmu Komunikasi Suatu Pengantar, Cet. II(Jakarta:PT Indeks, 2008).

- Wildan, Kepala Seksi Pengendalian dan Operasional Sudin Perhubungan Kota Admistrasi Jakarta Barat, pada tanggal 12 Februari 2019.

- Wanulu Ruky ah W anulu, MAKNA INTERAKSI SIMBOLIK PADA PROSESUPACARA ADAT CUMPE DAN SAMPUASUKU BUTON DI SAMARINDA, eJournal IlmuKomunikasi, 2016, 4 (3): 265-279ISSN 2502-597x, ejournal.ilkom.fisip-unmul.ac.id 
- Wahyu Ilawatus Z dan Refti Handini Listyani, Program Studi Sosiologi, Fakultas Ilmu Sosial dan Hukum, Universitas Negeri Surabaya, INTERAKSIONISME SIMBOLIK PEKERJA SEKS KOMERSIAL DI KARAOKE KELUARGA X2 SIDOARJO, Paradigma Journal. Volume 05. Nomor 03. Tahun 2017, Universitas Indonesia.

- Yin, Robert K, Studi Kasus Desain \& Metode, PT. Raja Grafindo Persada, Jakarta, 2013. 